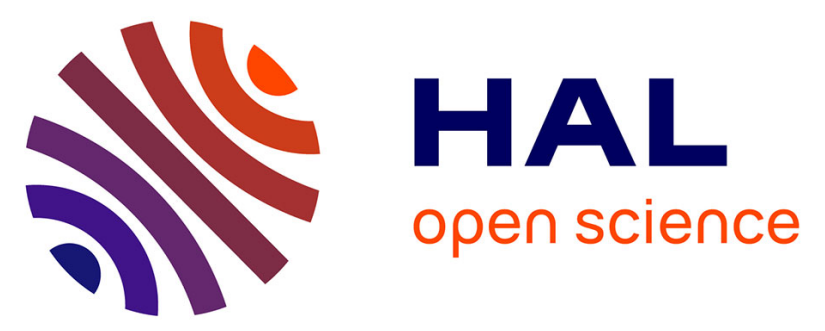

\title{
New cationic exchangers for the recovery of cobalt(II), nickel(II) and manganese(II) from acidic chloride solutions: Modelling of extraction curves
}

Kateryna Omelchuk, Alexandre Chagnes

\section{- To cite this version:}

Kateryna Omelchuk, Alexandre Chagnes. New cationic exchangers for the recovery of cobalt(II), nickel(II) and manganese(II) from acidic chloride solutions: Modelling of extraction curves. Hydrometallurgy, 2018, 180, pp.96-103. 10.1016/j.hydromet.2018.07.003 . hal-02182969

\section{HAL Id: hal-02182969 \\ https://hal.univ-lorraine.fr/hal-02182969}

Submitted on 8 Aug 2019

HAL is a multi-disciplinary open access archive for the deposit and dissemination of scientific research documents, whether they are published or not. The documents may come from teaching and research institutions in France or abroad, or from public or private research centers.
L'archive ouverte pluridisciplinaire HAL, est destinée au dépôt et à la diffusion de documents scientifiques de niveau recherche, publiés ou non, émanant des établissements d'enseignement et de recherche français ou étrangers, des laboratoires publics ou privés.

\section{(ㅇ)(1) $\$$}

Distributed under a Creative Commons Attribution - NonCommercial - NoDerivatives 44.0 


\title{
New cationic exchangers for the recovery of cobalt(II), nickel(II) and manganese(II) from acidic chloride solutions: Modelling of extraction curves
}

\author{
Kateryna Omelchuk ${ }^{\mathrm{a}}$ and Alexandre Chagnes ${ }^{\mathrm{b}, *}$
}

(a) PSL Research University, Chimie ParisTech - CNRS, Institut de Recherche de Chimie Paris, 11 rue Pierre et Marie Curie, 75005 Paris (France).

(b) Université de Lorraine, CNRS, GeoRessources, F- 54000 Nancy, France.

\begin{abstract}
The properties of six newly synthesized reagents for extraction of metal ions [Co(II), $\mathrm{Ni}(\mathrm{II})$ and $\mathrm{Mn}(\mathrm{II})]$ in chloride media were investigated, and the results with the standard extractants such as Cyanex 272, Cyanex 301, Ionquest 801 (DE2HPA) were compared. From these experimental results, a physicochemical model was developed to calculate the extraction curves of $\mathrm{Co}(\mathrm{II}), \mathrm{Ni}(\mathrm{II})$ and $\mathrm{Mn}(\mathrm{II})$. This model describes perfectly the extraction curves providing that extraction of $\mathrm{M}^{2+}$ and $\mathrm{MCl}^{+}\left(\mathrm{M}=\mathrm{Co}^{2+}\right.$, $\mathrm{Ni}^{2+}$ or $\mathrm{Mn}^{2+}$ ) as well as saponification and aggregation of extractants (dimer and trimer formation) were taken into account. Extraction constants of $\mathrm{M}^{2+}$ and $\mathrm{MCl}^{+}$as well as speciation diagrams in the extraction solvent as a function of $\mathrm{pH}$ were deduced from this model.
\end{abstract}

Keywords: Cobalt, nickel, manganese, solvent extraction, extractant, modelling.

To whom correspondence should be addressed (alexandre.chagnes@ $\underline{\text { univ-lorraine.fr). }}$ 


\section{Introduction}

Cobalt, nickel and manganese are used in electrode materials for lithium-ion batteries and alloys manufacturing (Chagnes and Pospiech, 2013; U.S. Geological Survey, 2018; U.S. Geological Survey, 2018a; U.S. Geological Survey, 2018b; U.S. Geological Survey, 2018c). The demand for these metals may grow tremendously because of the rapid growth of market for portable electronics, electric vehicles (EVs), and grid storage applications (Vikström, 2013). Their recovery from primary and secondary resources is therefore of great interest but their separation by solvent extraction is not necessarily easy. The most frequently used extracting agent for cobalt-nickel separation is Cyanex 272 (bis-(2,4,4-trimethylpentyl) phosphinic acid) (Flett, 2004). However, this extractant exhibits a low separation factor between cobalt(II) and manganese(II) both from acidic sulphate and chloride media (Omelchuk et al., 2017). Conversely, D2EHPA (bis-(2-ethyl-hexyl- phosphoric acid) is a suitable extractant for $\mathrm{Co}(\mathrm{II})-\mathrm{Mn}$ (II) separation from acidic chloride solutions (Zhao et al., 2011) but it is not appropriate for Co(II)-Ni(II) separation. Indeed, $\mathrm{pH}$ for which the extraction efficiency of $\mathrm{Mn}(\mathrm{II}), \mathrm{Co}(\mathrm{II})$ and $\mathrm{Ni}$ (II) from acidic chloride solution is equal to $50 \%\left(\mathrm{pH}_{1 / 2}\right)$ are 4.0, 4.3 and 6.7 when Cyanex 272 is used and 2.2, 3.3 and 3.8 when D2EHPA is employed instead of Cyanex 272, respectively (Omelchuk et al., 2017). The low $\mathrm{pH}$ of extraction implies that a large amount of alkaline solution has to be added in the leach solution to adjust the $\mathrm{pH}$ so that a selective extraction could be achieved, especially when Cyanex 272 is used to separate Co(II) and Ni(II). In order to decrease the operational expenditure, the design of new extracting agents capable to recover and separate $\mathrm{Co}(\mathrm{II}), \mathrm{Ni}(\mathrm{II})$ and $\mathrm{Mn}(\mathrm{II})$ at low $\mathrm{pH}$ and in few stages is highly required.

In our previous work (Omelchuk et al., 2017), the six synthesized extractants based on organophosphorus acids reported in Figure 1 were synthesized in order to investigate their extraction properties for the recovery of $\mathrm{Co}(\mathrm{II}), \mathrm{Ni}(\mathrm{II})$ and $\mathrm{Mn}(\mathrm{II})$ from acidic chloride media. The effects of structural changes of these organophosphorus cationic exchangers on the metal-distribution curves were investigated by using alkyl groups with different branching and hydrophobicity and by including oxygen atoms in the hydrophobic chains of the cationic exchangers. It was observed that changes of the chemical structure in the hydrophobic chains play an important role in the extraction behaviours and cause more specifically a shift of the extraction curves to higher or lower $\mathrm{pH}$ depending on $\mathrm{pK}_{\mathrm{a}}$ values of extracting 
agents, distribution constants of metal-ligand complexes between organic and aqueous phases and formation constants of metal-ligand complexes.

More recently, the aggregation behaviour and the acidic dissociation of these extractants were characterized by potentiometric titration and Vapour Pressure Osmometry (VPO) in acidic chloride solution and in $n$-heptane, respectively (Omelchuck et al., 2018). This study showed that the presence of sulphur increases the acidity of the molecules and $\mathrm{pK}_{\mathrm{a}}$ values are strongly affected by the presence of oxygen atoms in the hydrophobic chains. It was shown that $\mathrm{pK}_{\mathrm{a}}$ values increase according to the following order: phosphoric acid $<$ phosphonic acid $<$ phosphonic acid. Conversely, no significant effect of the hydrophobicity of the extractants on their acidity strength was observed. Aggregation characterization showed that bis(undecan6-yl) phosphoric acid (UPA) exhibits a weak association while the two isomers, i.e. bis(1,3-dibutoxypropan-2-yl) phosphoric acid (Bidibopp) and bis(1,3diisobutoxypropan-2-yl) phosphoric acid (IPA), form more dimers and trimers. All synthesized extractants exhibit very low aggregation constants compared to D2EHPA likely because of the high steric hindrance, which may not favour hydrogen bonds and may destabilize the aggregates.

In the present work, a physicochemical model has been developed to calculate the extraction efficiencies of $\mathrm{Co}(\mathrm{II}), \mathrm{Ni}$ (II) and $\mathrm{Mn}$ (II) from acidic chloride media as a function of $\mathrm{pH}$ for the six synthesized extractants reported in Figure 1 and three commercial extractants, i.e. D2EHPA, Cyanex 272 and Ionquest 801. This model relies on mass-balance equations and uses the aggregation and acidic dissociation constants determined in our previous work (Omelchuk et al., 2018).

\section{Material and Methods}

\subsection{Reagents}

The extractants reported in Figure 1 were synthesized according to the method reported previously (Omelchuk et al., 2018). Bis-(2-ethylhexyl)-phosphoric acid (D2EHPA, Aldrich, purity=97\%), Cyanex 272 (Cytec, purity >85\%), Ionquest 801 (Solvay, purity not specified), Cyanex 301 (Cytec, purity not specified) were used without further purification. Extraction solvents were prepared by diluting the commercial or synthesized extractants in kerosene (Sigma Aldrich, reagent grade, low odour, mixture of aliphatic hydrocarbons, less than $1 \%$ aromatics) without phase 
modifiers as no third-phase formation was observed.

Cobalt(II) nitrate hexahydrate $\left(\mathrm{Co}\left(\mathrm{NO}_{3}\right)_{2} \cdot 6 \mathrm{H}_{2} \mathrm{O}\right.$, Sigma Aldrich, purity $\left.\geq 98 \%\right)$, nickel(II) chloride hexahydrate $\left(\mathrm{NiCl}_{2} \cdot 6 \mathrm{H}_{2} \mathrm{O}\right.$, Sigma Aldrich, purity $\left.\geq 98 \%\right)$, manganese(II) chloride tetrahydrate $\left(\mathrm{MnCl}_{2} \cdot 4 \mathrm{H}_{2} \mathrm{O}\right.$, Sigma Aldrich, purity $\left.\geq 98 \%\right)$ were used to prepare feed solutions for liquid-liquid extraction experiments.

Feed solutions of $\mathrm{Ni}(\mathrm{II}), \mathrm{Co}(\mathrm{II})$ and $\mathrm{Mn}(\mathrm{II})$ at $1.17 \mathrm{~g} / \mathrm{L}(0.02 \mathrm{~mol} / \mathrm{L}), 1.18 \mathrm{~g} / \mathrm{L}$ $(0.02 \mathrm{~mol} / \mathrm{L})$ and $1.1 \mathrm{~g} / \mathrm{L}(0.02 \mathrm{~mol} / \mathrm{L})$ were prepared by dissolving the required amount of salts in $1 \mathrm{M}$ hydrochloric acid solutions.

\subsection{Metal-distribution curves (metal extraction efficiency vs. pH)}

The extraction properties of the organophosphorus acids towards $\mathrm{Co}(\mathrm{II}), \mathrm{Ni}$ (II) and $\mathrm{Mn}(\mathrm{II})$ in acidic chloride media were evaluated by plotting the metal distribution curves (extraction efficiency \%E vs. $\mathrm{pH}$ ). Extraction efficiency was calculated as follows:

$\% E=100 \frac{[M]_{\text {org }} V_{\text {org }}}{[M]_{\text {org }} V_{\text {org }}+[M]_{a q} V_{a q}}$

where $[\mathrm{M}]_{\text {org }}$ and $[\mathrm{M}]_{\mathrm{aq}}$ denote the metal concentrations at the equilibrium in organic and aqueous phases, respectively. $\mathrm{V}_{\text {org }}$ and $\mathrm{V}_{\mathrm{aq}, 0}$ denote the initial volume of the organic and aqueous phases, respectively.

In order to plot the metal-distribution curves, the $\mathrm{pH}$ values of the aqueous phases were adjusted by using $\mathrm{NaOH}$ and $\mathrm{HCl}$ (standard solution, Alfa Aesar). Batch experiments were conducted at $25^{\circ} \mathrm{C}$ in a flask containing equal volumes of aqueous and organic phases $\left(10 \mathrm{~mL} ; \mathrm{V}_{\text {org }} / \mathrm{V}_{\mathrm{aq}}=1\right)$. The $\mathrm{pH}$ of the aqueous phase was adjusted by using $\mathrm{NaOH}$ solution. The biphasic system was shaken with a Thermoshaker (Gerhardt) at $100 \mathrm{rpm}$ for 15 minutes. Preliminary experiments on the kinetic of extraction of $\mathrm{Ni}(\mathrm{II}), \mathrm{Co}(\mathrm{II})$ and $\mathrm{Mn}(\mathrm{II})$ showed that equilibrium was reached in all cases within 5 minutes of contact. After phase separation, the aqueous phase was filtered on nylon filter (VWR, Sartorius ${ }^{\circledR}, 0.20 \mu \mathrm{m}$ ) and the equilibrium $\mathrm{pH}$ of the aqueous phase was measured. Metal concentrations in aqueous solutions were determined by ICP-OES (ICAP 6000 Series, Thermo Scientific) at $243.7 \mathrm{~nm}$ for nickel, $237 \mathrm{~nm}$ for cobalt and $257 \mathrm{~nm}$ for manganese after diluting the sample in hydrochloric acid (ICP standard solution, 37\%, VWR). Metal ion concentration transferred from the aqueous phase into the organic phase was then deduced by mass balance in order to calculate the extraction efficiency defined in Eq. (1). Experiments were duplicated and the experimental error on the distribution coefficients of metals 
was estimated to be within 5\%.

\subsection{Biphasic potentiometric titration}

Biphasic potentiometric titrations were performed with a glass electrode (Metrohm ${ }^{\circledR} 913$ ) at $25{ }^{\circ} \mathrm{C}$ under nitrogen atmosphere (inert conditions) in order to investigate extractant saponification. Sodium hydroxide (Aldrich, analytical reagent) was used as titrant and sodium perchlorate (Aldrich, analytical reagent) was used to maintain the ionic strength at $1 \mathrm{~mol} \mathrm{~L}^{-1}$.

\subsection{Computing}

Computer simulations were carried out on a PC with the free mathematical software Scilab@ (Scilab, 1989-2005). The set of mass balance equations for the calculation of the speciation were solved by using the Powell method.

\section{Results and Discussion}

\subsection{Experimental data}

Liquid-liquid extraction of $\mathrm{Co}(\mathrm{II}), \mathrm{Ni}(\mathrm{II})$ and $\mathrm{Mn}(\mathrm{II})$ from acidic aqueous media by organophosphorus cationic exchangers involves the following general equilibrium (Komasawa et al., 1983; Danesi et al., 1985; Torkaman et al., 2017):

$M^{2+}+n(\overline{H L})_{2} \rightleftharpoons \overline{M\left(H L_{2}\right)_{2}\left(H_{2} L_{2}\right)_{n-2}}+2 H^{+}$

where $\mathrm{M}^{2+}$ represents $\mathrm{Co}^{2+}, \mathrm{Ni}^{2+}$ or $\mathrm{Mn}^{2+}$ and $\mathrm{HL}$ denotes the cationic exchanger (D2EHPA, Ionquest 810, Cyanex 272, etc.). The overbar indicates that the species are in the organic phase whereas the absence of overbar indicates the species are in the aqueous phase.

Figure 2 depicts the variation of the logarithm of the distribution ratio of $\mathrm{Co}(\mathrm{II})$, $\mathrm{Ni}(\mathrm{II})$ and $\mathrm{Mn}(\mathrm{II})$ as a function of $\mathrm{pH}$ when the aqueous phase initially contains 0.1 mol L-1 chloride and the organic phase is composed of one of the extractants reported in Figure 1 or commercial extractants, i.e. Cyanex 272, Cyanex 301, Ionquest 801 or D2EHPA. In most cases, slope reported in Figure 1 are quite different from 2. Therefore, the extraction equilibria of $\mathrm{Co}(\mathrm{II}), \mathrm{Ni}(\mathrm{II})$ and $\mathrm{Mn}$ (II) from aqueous phases containing $1 \mathrm{~mol} \mathrm{~L}^{-1}$ chloride are not the same as the equilibrium reported in Eq. (2) determined at chloride concentration lower than $1 \mathrm{~mol} \mathrm{~L}^{-1}$ or in acidic sulfate media.

This difference can be explained by the change of $\mathrm{Co}(\mathrm{II}), \mathrm{Ni}(\mathrm{II})$ and $\mathrm{Mn}(\mathrm{II})$ speciation as a function of chloride concentration. Figure 2 shows the speciation 
diagrams of these metals calculated by using equilibrium constants reported in Table 1. Although, this speciation diagram does not give the exact concentration since data have not been corrected by activity coefficients, this Figure shows the presence of the other metal chloride species $\mathrm{MCl}_{\mathrm{j}}{ }^{(2-\mathrm{j})}$ cannot be neglected, especially if some of them are extractable. At $1 \mathrm{~mol} \mathrm{~L}^{-1}$ chloride, $\mathrm{Co}(\mathrm{II})$ exists as $\mathrm{Co}^{2+}(13 \%), \mathrm{CoCl}^{+}(48 \%)$ and $\mathrm{CoCl}_{2}(39 \%), \mathrm{Ni}(\mathrm{II})$ exists as $\mathrm{Ni}^{2+}(27 \%), \mathrm{NiCl}^{+}(45 \%)$ and $\mathrm{NiCl}_{2}(28 \%)$ while $\mathrm{Mn}(\mathrm{II})$ exists as $\mathrm{Mn}^{2+}(55 \%), \mathrm{MnCl}^{+}(55 \%), \mathrm{MnCl}_{2}(25 \%)$ and $\mathrm{MnCl}_{3}{ }^{-}(6 \%)$.

Therefore, $\mathrm{Co}(\mathrm{II}), \mathrm{Ni}(\mathrm{II})$ and $\mathrm{Mn}(\mathrm{II})$ might be extracted by the cationic exchangers under the form of $\mathrm{Co}^{2+}, \mathrm{Ni}^{2+}$ and $\mathrm{Mn}^{2+}$ as well as $\mathrm{CoCl}^{+}, \mathrm{NiCl}^{+}$and $\mathrm{MnCl}^{+}$ according to the following equations:

$$
\begin{aligned}
& \mathrm{M}^{2+}+2 \overline{\mathrm{HL}} \rightleftharpoons \overline{M L_{2}}+2 \mathrm{H}^{+} \\
& \mathrm{MCl}^{+}+\overline{\mathrm{HL}} \rightleftharpoons \overline{M C l L}+\mathrm{H}^{+}
\end{aligned}
$$

The extraction of $\mathrm{M}^{2+}$ and $\mathrm{MCl}^{+}$species from the aqueous phase into the extraction solvent could therefore explain the reason why the slope of Log (D) vs. $\mathrm{pH}$ is lower than 2 .

The low values of the slopes in Figure 2 can also be explained by extractant saponification, which can be studied by biphasic titration involving the following biphasic reaction:

$$
\overline{\mathrm{HL}}+\mathrm{OH}^{-} \rightarrow \mathrm{H}_{2} \mathrm{O}+\mathrm{L}^{-}
$$

The biphasic titration curves have been modelled by solving Eqs. (5)-(6) deduced from the equilibria reported in Figure 4 and Eq. (7) derived from electroneutrality:

$$
\begin{aligned}
& {\left[L^{-}\right]\left(V_{a q, 0}+v\right)+\frac{\left[H^{+}\right]\left[L^{-}\right]}{K_{a}}\left(V_{a q, 0}+v\right)+\frac{P}{K_{a}}\left[H^{+}\right]\left[L^{-}\right] V_{\text {org }, 0}+} \\
& 2 K_{2}\left(\frac{P}{K_{a}}\right)^{2}\left[H^{+}\right]^{2}\left[L^{-}\right]^{2} V_{\text {org }, 0}+3 K_{3}\left(\frac{P}{K_{a}}\right)^{3}\left[H^{+}\right]^{3}\left[L^{-}\right]^{3} V_{\text {org }, 0}+\beta_{1}\left[N a^{+}\right]\left[L^{-}\right] V_{\text {org }, 0}+ \\
& 2 \beta^{\prime} \beta_{1} \frac{P}{K_{a}}\left[H^{+}\right]\left[N a^{+}\right]\left[L^{-}\right]^{2} V_{\text {org }, 0}+n \beta_{n} \beta_{1}^{n}\left[N a^{+}\right]^{n}\left[L^{-}\right]^{n} V_{\text {org }, 0}-[\overline{H L}]_{0} V_{\text {org }, 0}=0 \\
& {\left[N a^{+}\right]\left(V_{a q, 0}+v\right)+\beta_{1}\left[N a^{+}\right]\left[L^{-}\right] V_{\text {org }, 0}+\beta^{\prime} \beta_{1} \frac{P}{K_{a}}\left[H^{+}\right]\left[N a^{+}\right]\left[L^{-}\right]^{2} V_{\text {org }, 0}+} \\
& n \beta_{n} \beta_{1}^{n}\left[\mathrm{Na}^{+}\right]^{n}\left[L^{-}\right]^{n} V_{\text {org }, 0}-C_{\mathrm{NaClO}_{4}} V_{a q, 0}-C_{\mathrm{NaOH}} v=0 \\
& {\left[\mathrm{Na}^{+}\right]+\left[\mathrm{H}^{+}\right]-\frac{K_{w}}{\left[\mathrm{H}^{+}\right]}-\frac{\mathrm{C}_{\mathrm{NaClO}_{4}} \mathrm{Vaq}, 0}{V_{a q, 0}+v}-\left[L^{-}\right]=0}
\end{aligned}
$$

where $\mathrm{V}_{\text {org }, 0}, \mathrm{~V}_{\mathrm{aq}, 0}$ and $v$ denote the initial volume of the organic phase (the volume of the organic phase at the equilibrium is equal to the initial volume of the organic phase given that there is no significant variation of the organic phase volume during 
the titration), the initial volume of the aqueous phase and the volume of sodium hydroxide added during the biphasic titration, respectively. $\mathrm{C}_{\mathrm{NaOH}}$ and $\mathrm{C}_{\mathrm{NaClO}_{4}}$ are sodium hydroxide concentration and sodium perchlorate concentration (sodium perchlorate is used to maintain ionic strength at $\left.1 \mathrm{~mol} \mathrm{~L}^{-1}\right)$. All of the constants reported in Eqs (5)-(7) are defined in Figure 4.

Values of acidic constants of the extractants $\left(\mathrm{K}_{\mathrm{a}}\right)$, partition constants of the monomeric form of the extractants $(\mathrm{P})$, dimerization and trimerization constants of the extractants $\left(\mathrm{K}_{2}\right.$ and $\mathrm{K}_{3}$, respectively) were determined by our group in a previous work (Omelchuk et al., 2018). Values of $\beta_{1}, \beta^{\prime}, \beta_{\mathrm{n}}$ and $\mathrm{n}$ were adjusted in order to have the best accordance between experimental and calculated biphasic titration curves.

To assess the relative success of the model, a linear square regression analysis of the form:

$$
\mathrm{pH}_{\mathrm{calc}}=\mathrm{u} \mathrm{pH}_{\exp }
$$

was employed where $\mathrm{pH}_{\text {calc }}$ and $\mathrm{pH}_{\exp }$ represent calculated and experimental values of $\mathrm{pH}$ during the titration, respectively. The resulting values of the slope $\mathrm{u}$ and the correlation coefficients $\left(\mathrm{R}^{2}\right)$ reported in Table 3 are sufficiently close to unity to estimate that a good agreement was obtained between experimental titration curves and titration curves calculated by using the constants reported in Table 2. For the sake of illustration, Figure 5 displays the calculated and experimental biphasic potentiometric titration curves for the synthesized extractants diluted in kerosene in contact with an aqueous phase containing $1 \mathrm{~mol} \mathrm{~L}^{-1}$ sodium perchlorate.

The previous model including the constants reported in Table 2 has been used to calculate the saponification percentage ( $\rho_{\text {sapo }}$ ) of the extractants defined by Eq. (9).

$$
\rho_{\text {sapo }}=100 \frac{[\overline{N a L}]+2\left[\overline{N a H L_{2}}\right]+n\left[(\overline{N a L})_{n}\right]}{[\overline{N a L}]+2\left[\overline{N a H L_{2}}\right]+n\left[(\overline{N a L})_{n}\right]+[\overline{H L}]+2\left[(\overline{H L})_{2}\right]+3\left[(\overline{H L})_{3}\right]}
$$

Figure 6 shows that saponification is not negligible and may explain the low slopes deduced in Figure 1. Therefore, the physicochemical model used for describing extraction curves should take into account both the presence of $\mathrm{MCl}^{+}$in acidic chloride media $(\mathrm{M}=\mathrm{Co}, \mathrm{Ni}, \mathrm{Mn})$ and extractant saponification when sodium hydroxide is used to control the $\mathrm{pH}$ during liquid-liquid extraction experiments. 


\subsection{Modelling of the extraction curves of $\mathrm{Co}(\mathrm{II}), \mathrm{Ni}(\mathrm{II})$ and $\mathrm{Mn}(\mathrm{II})$}

\subsubsection{Physicochemical model}

The equilibria reported in Figure 7 have been used to model the variation of the extraction efficiency as a function of $\mathrm{pH}$ during the liquid-liquid extraction of $\mathrm{Co}(\mathrm{II})$, $\mathrm{Ni}(\mathrm{II})$ and $\mathrm{Mn}$ (II) from an aqueous phase containing $1 \mathrm{~mol} \mathrm{~L}^{-1}$ chloride. The following equations were solved to calculate the extraction curves:

$$
\begin{aligned}
& {[H L] V_{\text {org }}+2 K_{2}[\overline{H L}]^{2} V_{\text {org }}+3 K_{3}[\overline{H L}]^{3} V_{\text {org }}+\frac{\beta_{1} K_{a}\left[\mathrm{Na}^{+}\right][\overline{\mathrm{HL}}]}{P\left[\mathrm{H}^{+}\right]} V_{\text {org }}+} \\
& 2 \beta^{\prime} \beta_{1} \frac{K_{a}\left[\mathrm{Na}^{+}\right][\overline{\mathrm{HL}}]^{2}}{P\left[\mathrm{H}^{+}\right]} V_{\text {org }}+\frac{n \beta_{n} \beta_{1}^{n} K_{a}^{n}\left[\mathrm{Na}^{+}\right]^{n}[\overline{\mathrm{HL}}]^{n}}{P^{n}\left[\mathrm{H}^{+}\right]^{n}} V_{\text {org }}+2 \frac{K_{\text {ex } 1} K_{a}^{2}\left[\mathrm{M}^{2+}\right][\overline{\mathrm{HL}}]^{2}}{P^{2}\left[\mathrm{H}^{+}\right]^{2}} V_{\text {org }}+ \\
& \frac{K_{e x 2} \beta_{2} K_{a}\left[M^{2+}\right]\left[C l^{-}\right][\overline{H L}]}{P\left[H^{+}\right]} V_{\text {org }}+\frac{K_{a}[\overline{H L}]}{P\left[H^{+}\right]} V_{a q}+\frac{[\overline{H L}]}{P} V_{a q}-[\overline{H L}]_{0} V_{\text {org }, 0}=0 \\
& {\left[N a^{+}\right] V_{a q}+\frac{\beta_{1} K_{a}\left[\mathrm{Na}^{+}\right][\overline{\mathrm{HL}}]}{P\left[\mathrm{H}^{+}\right]} V_{\text {org }}+\frac{\beta^{\prime} \beta_{1} K_{a}\left[\mathrm{Na} a^{+}\right][\overline{\mathrm{HL}}]^{2}}{P\left[\mathrm{H}^{+}\right]} V_{\text {org }}+\frac{n \beta_{n} \beta_{1}^{n} K_{a}^{n}\left[\mathrm{Na}^{+}\right]^{n}[\overline{\mathrm{HL}}]^{n}}{P^{n}\left[\mathrm{H}^{+}\right]^{n}} V_{\text {org }}-} \\
& {\left[\mathrm{Na}^{+}\right]_{0} V_{a q, 0}=0} \\
& {\left[\mathrm{M}^{2+}\right] V_{a q}+\beta_{2}\left[\mathrm{M}^{2+}\right]\left[\mathrm{Cl}^{-}\right] V_{a q}+\beta_{3}\left[\mathrm{MCl}^{+}\right]\left[\mathrm{Cl}^{-}\right] V_{a q}+\beta_{4}\left[\mathrm{MCl}_{2}\right]\left[\mathrm{Cl}^{-}\right] V_{a q}+} \\
& \frac{K_{e x 1} K_{a}^{2}\left[M^{2+}\right][\overline{H L}]^{2}}{P^{2}\left[H^{+}\right]^{2}} V_{\text {org }}+\frac{K_{e x 2} \beta_{2} K_{a}\left[M^{2+}\right]\left[C l^{-}\right][\overline{H L}]}{P\left[H^{+}\right]} V_{\text {org }}-\left[M^{2+}\right]_{0} V_{a q, 0}=0 \\
& {\left[\mathrm{Cl}^{-}\right] V_{a q}+\beta_{2}\left[\mathrm{M}^{2+}\right]\left[\mathrm{Cl}^{-}\right] V_{a q}+\beta_{3}\left[\mathrm{MCl}^{+}\right]\left[\mathrm{Cl}^{-}\right] V_{a q}+\beta_{4}\left[\mathrm{MCl}_{2}\right]\left[\mathrm{Cl}^{-}\right] V_{a q}+} \\
& \frac{K_{e x 2} \beta_{2} K_{a}\left[M^{2+}\right]\left[C l^{-}\right][\overline{H L}]}{P\left[H^{+}\right]} V_{o r g}-\left[C l^{-}\right]_{0} V_{a q, 0}=0 \\
& 2\left[\mathrm{M}^{2+}\right]+\left[\mathrm{MCl}^{+}\right]+\left[\mathrm{Na}^{+}\right]+\left[\mathrm{H}^{+}\right]-\frac{K_{w}}{\left[\mathrm{H}^{+}\right]}-\left[\mathrm{L}^{-}\right]-\left[\mathrm{Cl}^{-}\right]-\left[\mathrm{MCl}_{3}^{-}\right]=0 \\
& \text { with } \\
& {\left[L^{-}\right]=\frac{K_{a}[\overline{H L}]}{P\left[H^{+}\right]}}
\end{aligned}
$$

In these equations, $K_{w}=10^{-14}, K_{a}, K_{2}, K_{3}, b_{1}, b_{2}, b_{3}, \beta_{1}, \beta, \beta_{n}$ and $n$ are reported in tables 1 and 2. The values of $K_{\text {ex } 1}$ and $K_{\text {ex2 }}$ defined in Figure 7 were adjusted in order to achieve the best accordance between experimental and calculated extraction curves.

\subsubsection{Extraction curves modelling}

Figure 8 shows the extraction curves of $\mathrm{Co}(\mathrm{II}), \mathrm{Ni}(\mathrm{II})$ and $\mathrm{Mn}$ (II) from acidic chloride media $\left(\left[\mathrm{Cl}^{-}\right]=1 \mathrm{~mol} \mathrm{~L}^{-1}\right)$ by the commercial and synthesized extractants diluted in kerosene. A good agreement between experimental and calculated extraction curves were found since the value of $\mathrm{w}$ and the correlation coefficient $\left(\mathrm{R}^{2}\right)$ defined in Eq. (16) are closed to unity (see Table 4).

$\rho_{\mathrm{M}, \mathrm{calc}}=\mathrm{W} \rho_{\mathrm{M}, \exp }$ 
By using the equilibrium constants reported in Tables 1 and 2, this model allows determining the extraction constants $\mathrm{K}_{\mathrm{ex} 1}$ and $\mathrm{K}_{\mathrm{ex} 2}$ related to the extraction of $\mathrm{M}^{2+}$ and $\mathrm{MCl}^{+}$, respectively. These values are reported in Table 5. Experimental $\mathrm{pK}_{\mathrm{a}}$ values reported in our previous paper (Omelchuk et al., 2018) have been used in the model excepting for modelling metal extraction by Bidibopp, Ionquest 801, IPA and TPA for which $\mathrm{pK}_{\mathrm{a}}=2.8,4.6,2.8$ and 3.5 have been used in the model instead of 2.4, 3.0, 2.5 and 2.3, respectively. However, such differences between $\mathrm{pK}_{\mathrm{a}}$ values determined by potentiometric titration and by the present model are not significant since experimental conditions are different $\left(0.1 \mathrm{~mol} \mathrm{~L}^{-1}\right.$ instead of $1 \mathrm{~mol} \mathrm{~L}^{-1}$ chloride).

The physicochemical model has been used to calculate the speciation in the loaded and do not depend on the extractant. Concentrations of $\mathrm{NiL}_{2}, \mathrm{CoL}_{2}$ and $\mathrm{MnL}_{2}$ in extraction solvent increase when $\mathrm{pH}$ increases until a plateau corresponding to the full metal extraction. The plots of the concentrations of NiClL, CoClL and MnClL in organic phase as a function of $\mathrm{pH}$ exhibit a maximum value that depends markedly on the nature of the extractant.

It is interesting to highlight that the concentration of $\mathrm{MnL}_{2}$ is greater than that of $\mathrm{NiL}_{2}$ and $\mathrm{CoL}_{2}$ in the organic phase whatever the extractant, excepting for Cyanex 301. In the presence of this extractant, the concentration of $\mathrm{CoL}_{2}$ is greater than that of $\mathrm{MnL}_{2}$. Such an observation is coherent with the Pearson theory, which predicts that $\mathrm{Mn}^{2+}$ is harder than $\mathrm{Co}^{2+}$ and $\mathrm{Ni}^{2+}$. Likewise, it can be inferred that $\mathrm{MnCl}^{+}$is harder than $\mathrm{CoCl}^{+}$and $\mathrm{NiCl}^{+}$.

\section{Conclusion}

The extraction of $\mathrm{Co}(\mathrm{II}), \mathrm{Ni}(\mathrm{II})$ and $\mathrm{Mn}(\mathrm{II})$ from aqueous solutions containing 1 mol L ${ }^{-1}$ chloride by commercial organophosphorus cationic exchangers and six new organophosphorus acids involves the extraction of $\mathrm{M}^{2+}$ and $\mathrm{MCl}^{+}\left(\mathrm{M}^{2} \mathrm{Co}^{2+}, \mathrm{Ni}^{2+}\right.$ or $\mathrm{Mn}^{2+}$ ). Therefore, the extraction equilibria are different than those occurring in the presence of aqueous solutions containing chloride ions at concentration lower than 1 mol L-1. Such an observation is coherent with the speciation diagram of these metals in acidic chloride media. Modelling of the extraction curves of $\mathrm{Co}(\mathrm{II}), \mathrm{Ni}(\mathrm{II})$ and $\mathrm{Mn}(\mathrm{II})$ in $1 \mathrm{~mol} \mathrm{~L}^{-1}$ chloride by these extractants has been successfully performed by taking into account extraction of $\mathrm{M}^{2+}$ and $\mathrm{MCl}^{+}$ions, extractant saponification, acidbase properties of the extractants and their aggregation in kerosene. 


\section{References}

Chagnes, A and Pospiech, B., 2013. A brief review on hydrometallurgical technologies for recycling spent lithium-ion batteries. J. Chem. Technol. Biotechnol. 88, 1191-1199.

Danesi, P. R., Reichley-Yinger, L. Mason, G., Kaplan, L., Horwltz, E.P., Diamond, H., 1985. Selectivity-structure trends in the extraction of Co(II) and Ni(II) by dialkyl phosphoric, alkyl alkylphosphonic and dialkylphosphinic acids, 1985. Solv. Extr. Ion Exch. 3 (4) 435-52.

Flett, D, 2004. Cobalt-Nickel Separation in Hydrometallurgy: a Review. Chemistry for Sustainable Development 12, 81-91.

Komasawa, I., Tsutao O., 1983. The Effects of Diluent in the Liquid-Liquid, Extraction of Copper and Nickel Using 2-Hydroxy-5-Nonylbenzophenone Oxime. J. Chem. Eng. Japan 16(5), 377-383.

Morris, D. F. C., Reed, G. L., Short, E. L., Slater, D. N., Waters, D. N., 1965. Nickel (II) Chloride Complexes in Aqueous Solution. J. Inorg. Nucl. Chemistry 27 (2), $377-$ 82.

Omelchuk, K., Szczepaski, P., Shrotre, A., Haddad, M., Chagnes, A., 2017. Effects of structural changes of new organophosphorus cationic exchangers on a solvent extraction of cobalt, nickel and manganese from acidic chloride media. RSC Adv. 7, $5660-5668$.

Omelchuk, K., Stambouli, M. Chagnes, A., 2018. Investigation of aggregation and acid dissociation of new cationic exchangers for liquid-liquid extraction". Journal of Molecular Liquids. Doi.org/10.1016/j.molliq.2018.04.082.

Torkaman, R., Asadollahzadeh, M., Torab-Mostaedi, M., Ghanadi Maragheh, M, 2017. Recovery of Cobalt from Spent Lithium Ion Batteries by Using Acidic and Basic Extractants in Solvent Extraction Process. Sep. Purif. Technol. 186, 318-325.

U.S. Geological Survey, January 2018a. Cobalt. Mineral Commodity Summaries p. 50.

U.S. Geological Survey, January 2018b. Manganese. Mineral Commodity Summaries p. 104-105.

U.S. Geological Survey, January 2018c. Nickel. Mineral Commodity Summaries p. 112-113.

Vikström, H., Davidsson, S., Höök, 2013. Lithium availability and future production outlooks. Appl. Energy 110, 252-266.

Zhao, J. M., Shen, X. Y, Deng, .F. L., Wang, F. C., Wu, Y., Liu, H. Z., 2011. Synergistic extraction and separation of valuable metals from waste cathodic material of lithium ion batteries using Cyanex272 and PC-88A. Sep. Purif. Technol. 78, 345351 . 


\section{Tables}

Table 1 : Formation constants $\beta_{c, j}$ of $\mathrm{MCl}_{\mathrm{j}}{ }^{(2-\mathrm{j})}\left(\mathrm{M}=\mathrm{Co}^{2+}, \mathrm{Ni}^{2+}\right.$ and $\left.\mathrm{Mn}^{2+}\right)$ at $20{ }^{\circ} \mathrm{C}$ and an ionic strength $\mathrm{I}=0.691 \mathrm{~mol} \mathrm{~L}^{-1}$ (Morris et al., 1965).

\begin{tabular}{cccc}
\hline Metal & $\log \left(\boldsymbol{\beta}_{\mathrm{c}, \mathbf{1}}\right)$ & $\log \left(\boldsymbol{\beta}_{\mathrm{c}, \boldsymbol{2}}\right)$ & $\log \left(\boldsymbol{\beta}_{\mathrm{c}, \boldsymbol{3}}\right)$ \\
\hline $\mathrm{Mn}^{2+}$ & 0.59 & 0.26 & -0.36 \\
$\mathrm{Co}^{2+}$ & 0.69 & 0.51 & - \\
$\mathrm{Ni}^{2+}$ & 0.23 & -0.04 & - \\
\hline
\end{tabular}

Table 2 : Equilibrium constants of the physicochemical model of saponification at 25 ${ }^{\circ} \mathrm{C} . \mathrm{P}, \mathrm{pK}_{\mathrm{a}}, \mathrm{K}_{2}$ and $\mathrm{K}_{3}$ were reported in (Omelchuk et al., 2018). $\beta_{1}, \beta^{\prime}, \beta_{\mathrm{n}}$ and $\mathrm{n}$ were determined in the present paper by modeling the biphasic potentiometric titration curves.

\begin{tabular}{|c|c|c|c|c|c|c|c|c|c|c|}
\hline & 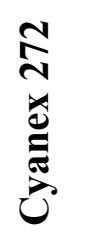 & 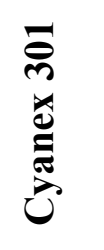 & 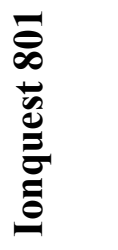 & 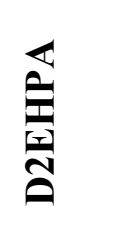 & 号 & 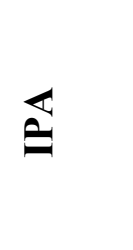 & $\overleftrightarrow{a}$ & 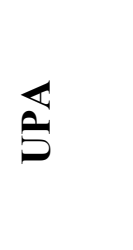 & $\widehat{\bar{o}}$ & $\underset{\mathbf{I}}{\overleftrightarrow{\mid r}}$ \\
\hline $\mathbf{P}$ & 657 & 1231 & 88 & 211 & 40539 & 34972 & 30000 & 13252 & 31723 & 31723 \\
\hline $\mathbf{p K} \mathbf{K}_{\mathbf{a}}$ & 4.2 & 2.9 & 3.0 & 2.6 & 2.4 & 2.5 & 2.3 & 3.5 & 3.1 & 3.1 \\
\hline $\mathbf{K}_{2}$ & 190 & 5 & 2703 & 184 & 3 & 6 & 5 & 2 & 4 & 4 \\
\hline $\mathbf{K}_{\mathbf{3}}$ & 0 & 0 & 0 & 8385 & 9 & 10 & 0 & 0 & 0 & 0 \\
\hline$\beta_{1}$ & 1.5 & 0,5 & 20 & 8 & 600 & 80 & 3500 & 3 & 5800 & 5800 \\
\hline$\beta^{\prime}$ & 20 & 2 & 120 & 230 & 210 & 1000 & 150 & 4 & 150 & 150 \\
\hline$\beta_{\mathbf{n}}$ & $10^{5}$ & $10^{13}$ & 0 & $10^{7}$ & $10^{10}$ & $10^{13}$ & $10^{13}$ & $10^{4}$ & $10^{6}$ & $10^{6}$ \\
\hline $\mathbf{n}$ & 5 & 7 & 5 & 7 & 5 & 5 & 5 & 5 & 5 & 5 \\
\hline
\end{tabular}


Table 3 : Quality factors of the physicochemical model describing extractant saponification.

\begin{tabular}{ccc}
\hline & $\mathbf{u}$ & $\boldsymbol{R}^{\mathbf{2}}$ \\
\hline Cyanex ${ }^{\circledR} 272$ & 0.997 & 0.954 \\
Cyanex ${ }^{\circledR} 301$ & 0.964 & 0.940 \\
Ionquest ${ }^{\circledR} 801$ & 0.957 & 0.952 \\
D2EHPA & 1.001 & 0.973 \\
Bidibopp & 1.021 & 0.991 \\
IPA & 0.998 & 0.987 \\
TPA & 1.006 & 0.966 \\
UPA & 0.983 & 0.990 \\
OPA & 0.985 & 0.981 \\
EHPA & 1.010 & 0.984 \\
\hline
\end{tabular}

Table 4: Quality factors of the physicochemical model describing the extraction curves of $\mathrm{Co}(\mathrm{II}), \mathrm{Ni}(\mathrm{II})$ and $\mathrm{Mn}(\mathrm{II})$ by cationic exchangers from acidic chloride media $\left.\left(\mathrm{Cl}^{-}\right]=1 \mathrm{~mol} \mathrm{~L}^{-1}\right)$.

\begin{tabular}{ccccccc}
\hline & \multicolumn{2}{c}{ Co(II) } & \multicolumn{2}{c}{ Ni(II) } & \multicolumn{2}{c}{ Mn(II) } \\
& $\mathbf{w}$ & $\mathbf{R}^{\mathbf{2}}$ & $\mathbf{W}$ & $\mathbf{R}^{\mathbf{2}}$ & $\mathbf{w}$ & $\mathbf{R}^{\mathbf{2}}$ \\
\hline Cyanex ${ }^{\circledR} 272$ & 0.973 & 0.986 & 0.997 & 0.993 & 1.003 & 0.999 \\
Cyanex® 301 & 0.971 & 0.970 & - & - & 0.997 & 0.999 \\
$\begin{array}{c}\text { Ionquest }{ }^{\circledR} \\
\text { 801 }\end{array}$ & 1.010 & 0.976 & 1.066 & 0.983 & 1.028 & 0.997 \\
D2EHPA & 1.000 & 0.997 & 0.979 & 0.996 & 1.001 & 0.995 \\
Bidibopp & 0.984 & 0.997 & 1.000 & 0.997 & 0.977 & 0.991 \\
IPA & 1.02 & 0.990 & 1.050 & 0.975 & 0.996 & 0.997 \\
TPA & 0.986 & 0.994 & 1.000 & 0.996 & 1.018 & 0.997 \\
UPA & 1.090 & 0.991 & - & - & 1.002 & 0.999 \\
OPA & 1.015 & 0.998 & - & - & 1.006 & 0.998 \\
EHPA & 0.973 & 0.982 & - & - & 0.994 & 0.998 \\
\hline
\end{tabular}


Table 5: Extraction constants of $\mathrm{M}^{2+}$ and $\mathrm{MCl}^{+}(\mathrm{M}=\mathrm{Co}(\mathrm{II}), \mathrm{Ni}(\mathrm{II})$ and $\mathrm{Mn}(\mathrm{II})$ ) from acidic aqueous solutions containing $1 \mathrm{~mol} \mathrm{~L}^{-1}$ chloride and an organic phase containing a cationic exchanger in kerosene. *Values had to be adjusted to achieve a good agreement between experimental and calculated extraction curves beside $\mathrm{K}_{\mathrm{ex} 1}$ and $\mathrm{K}_{\mathrm{ex} 1}\left(\mathrm{pK}_{\mathrm{a}}=2.8\right.$ for Bidibopp, 4.2 for EHPA, 4.6 for Ionquest 801, 2.8 for IPA). ** $\mathrm{pK}_{\mathrm{a}}$ values from QSPR calculation $\left(\mathrm{pK}_{\mathrm{a}}=3.07\right.$ for OPA and 3.55 for TPA) (Omelchuk et al., 2017).

\begin{tabular}{ccccccc}
\hline \multirow{2}{*}{ Extractants } & \multicolumn{2}{c}{ Co(II) } & \multicolumn{2}{c}{ Ni(II) } & \multicolumn{2}{c}{ Mn(II) } \\
& $\mathbf{K}_{\text {ex, } \mathbf{1}}$ & $\mathbf{K}_{\text {ex }, \mathbf{2}}$ & $\mathbf{K}_{\text {ex }, \mathbf{1}}$ & $\mathbf{K}_{\mathbf{e x}, \mathbf{2}}$ & $\mathbf{K}_{\mathbf{e x}, \mathbf{1}}$ & $\mathbf{K}_{\mathbf{e x}, \mathbf{2}}$ \\
\hline Bidibopp* & $4.10^{12}$ & $8.10^{5}$ & $6.10^{11}$ & $5.10^{5}$ & $3.10^{14}$ & 0 \\
Cyanex 272 & $3.10^{9}$ & $5.10^{3}$ & $6.10^{3}$ & $2.10^{2}$ & $10^{10}$ & $3.10^{4}$ \\
Cyanex 301 & $4.10^{13}$ & 0 & - & - & $10^{7}$ & $9.10^{3}$ \\
D2EHPA & $2.10^{7}$ & $3.10^{3}$ & $2.10^{6}$ & $5.10^{2}$ & $3.10^{9}$ & $2.10^{4}$ \\
EHPA* & $2.10^{12}$ & $4.10^{5}$ & - & - & $4.10^{15}$ & $10^{7}$ \\
Ionquest 801* & $10^{11}$ & $5.10^{5}$ & $5.10^{8}$ & $3.10^{3}$ & $5.10^{11}$ & $5.10^{5}$ \\
IPA* & $10^{12}$ & $3.10^{5}$ & $2.10^{11}$ & $4.10^{5}$ & $10^{14}$ & $6.10^{6}$ \\
OPA** & $2.10^{13}$ & $2.10^{6}$ & - & - & $10^{15}$ & 0 \\
TPA** & $3.10^{14}$ & $5.10^{6}$ & $2.10^{14}$ & $10^{6}$ & $10^{16}$ & 0 \\
UPA & $8.10^{8}$ & $5.10^{4}$ & - & - & $3.10^{10}$ & $5.10^{5}$ \\
\hline
\end{tabular}




\section{Figures}

Bis(1,3-dibutoxypropan-2-yl)phosphoric acid (Bidibopp)

Bis(1,3-diisobutoxypropan-2-yl) phosphoric acid (IPA)

Bis(5,8,12,15-tetraoxanonadecan-10yl)-phosphoric acid (TPA)

Bis(undecan-6-yl)-phosphoric acid (UPA)

Bis(1,3-dioctyloxypropan-2-yl)phosphoric acid (OPA)

Bis(1,3-di-2-ethylhexyloxypropan-2yl) phosphoric acid (EHPA)

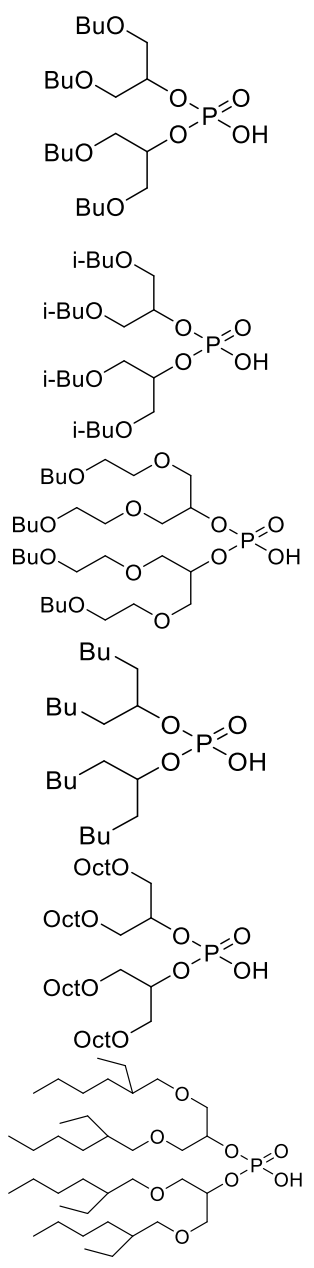

Figure 1: Synthesized extractants derived from D2EHPA. 
(a)

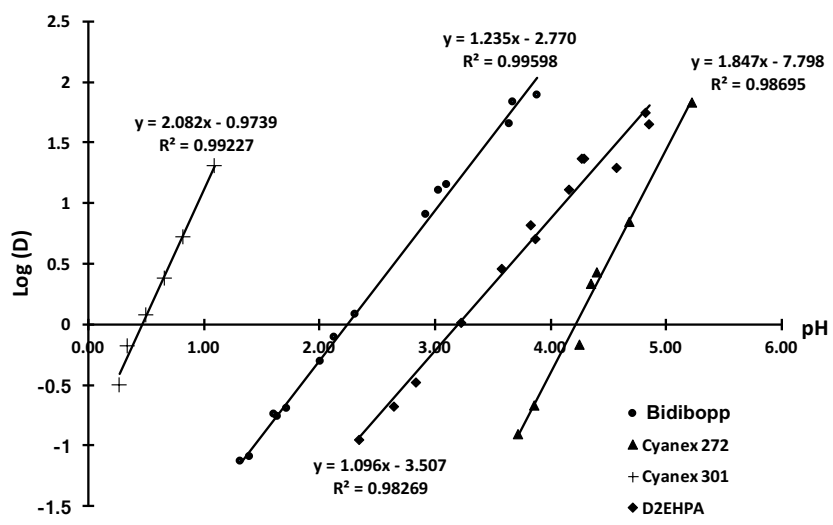

(c)

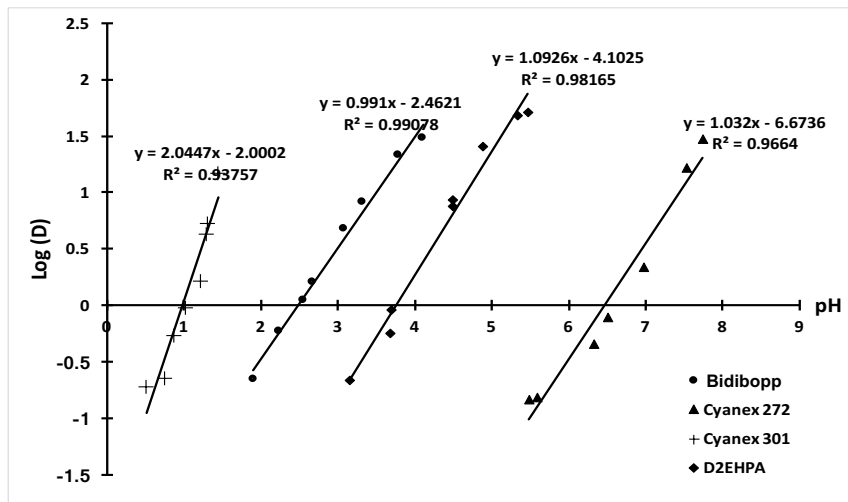

(e)

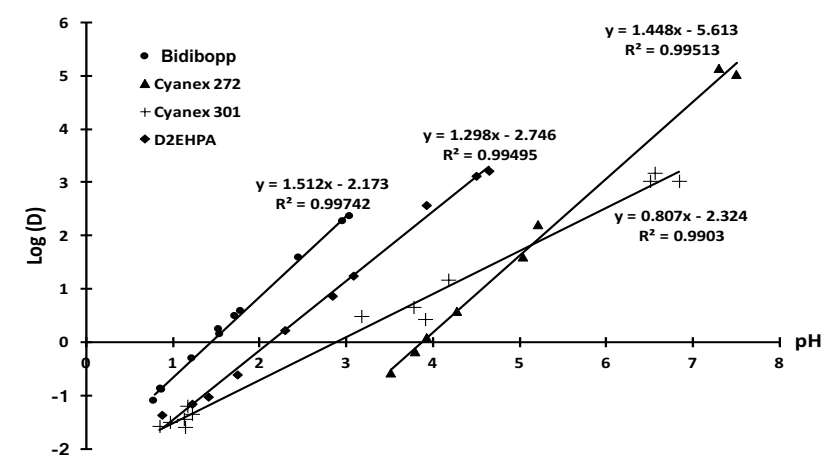

(b)

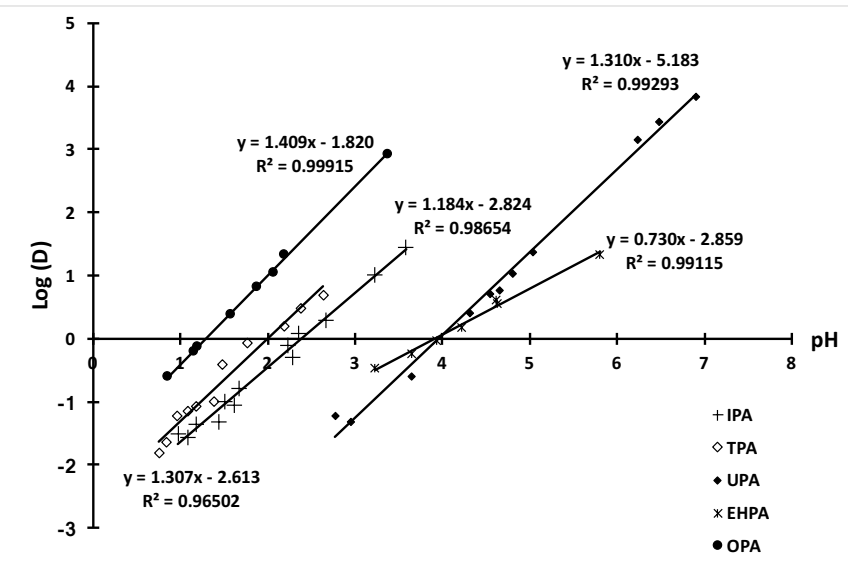

(d)

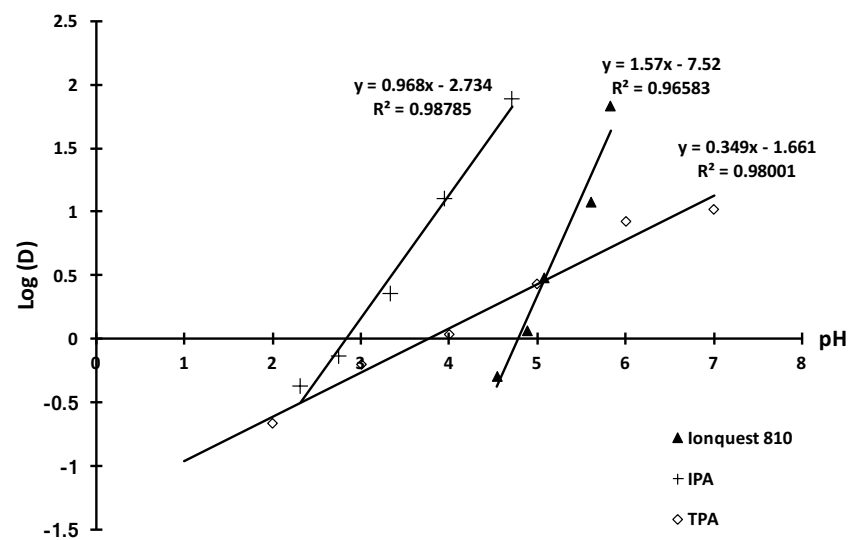

(f)

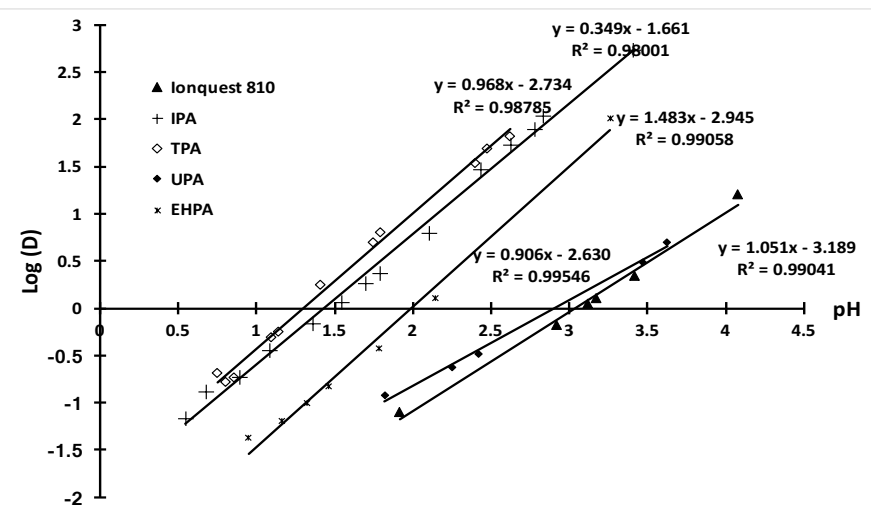

Figure 2: Variation of the logarithm of the distribution ratio of (a) cobalt(II), (b) nickel(II) and (c) manganese(II) as the function of $\mathrm{pH}$ at the equilibrium. Organic phase: cationic exchanger in Figure 1 diluted in kerosene; aqueous phase: $1 \mathrm{~mol} \mathrm{~L}^{-1}$ chloride; temperature $=25^{\circ} \mathrm{C}$; phase volume ratio $\mathrm{V}_{\text {org }} / \mathrm{V}_{\mathrm{aq}}=1$. 
(a)

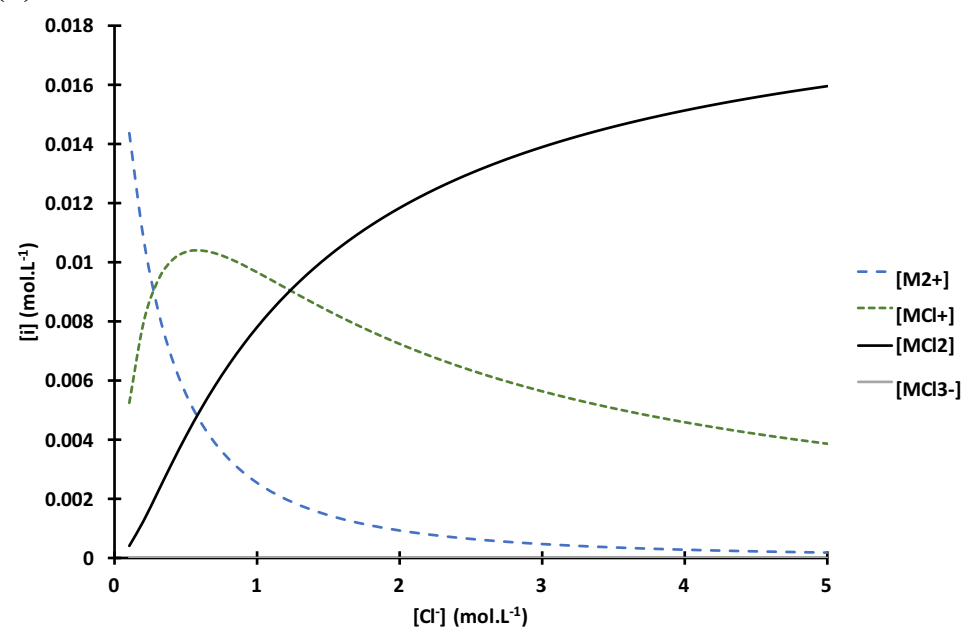

(b)

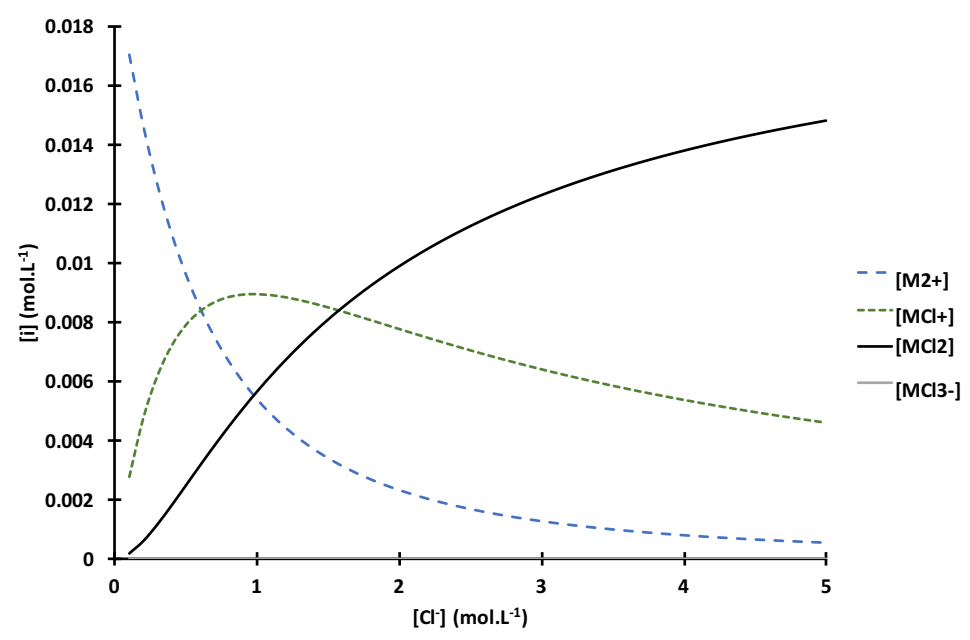

(c)

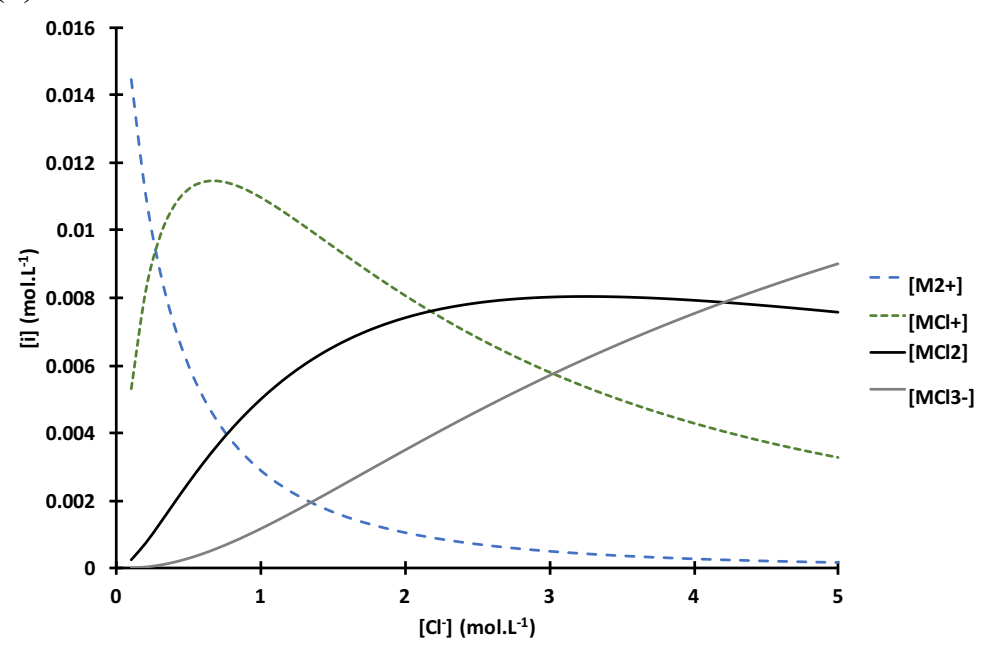

Figure 3: Speciation diagram of $\mathrm{Co}(\mathrm{II})$, (b) $\mathrm{Ni}(\mathrm{II})$ and (c) $\mathrm{Mn}$ (II) as a function of chloride concentration at $\mathrm{pH}$ low enough to neglect hydrolysis. This speciation diagram is only for a sake of illustration as data were not corrected from non-ideality. 


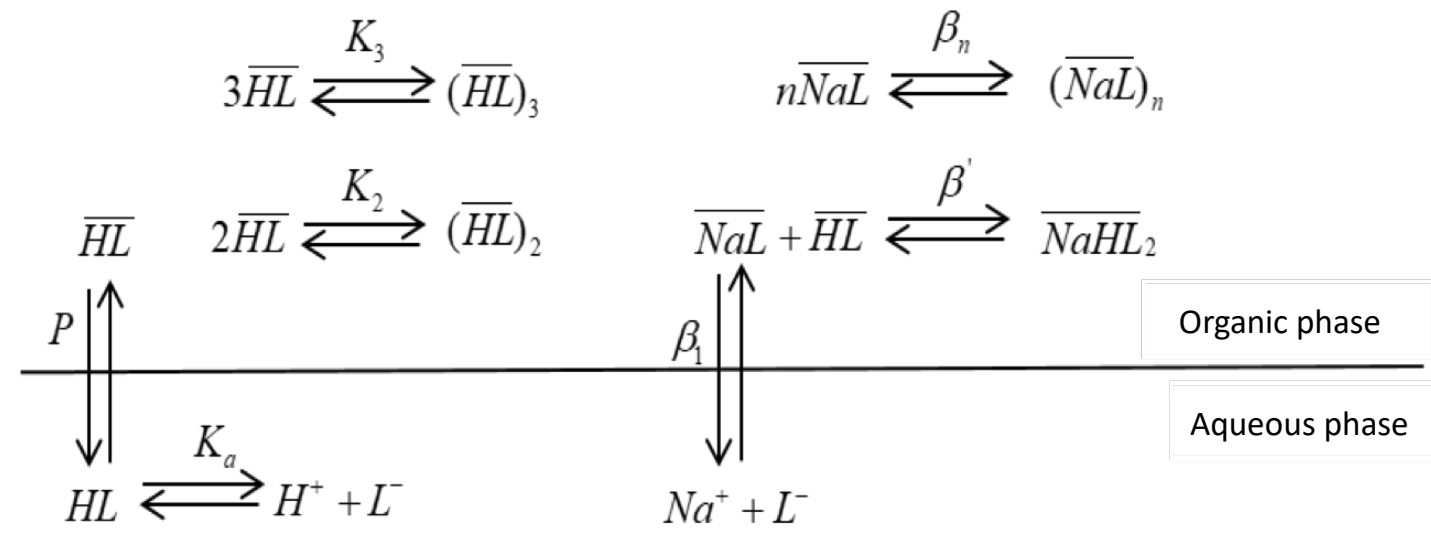

Figure 4: Equilibria used for the investigation of extractant saponification. 


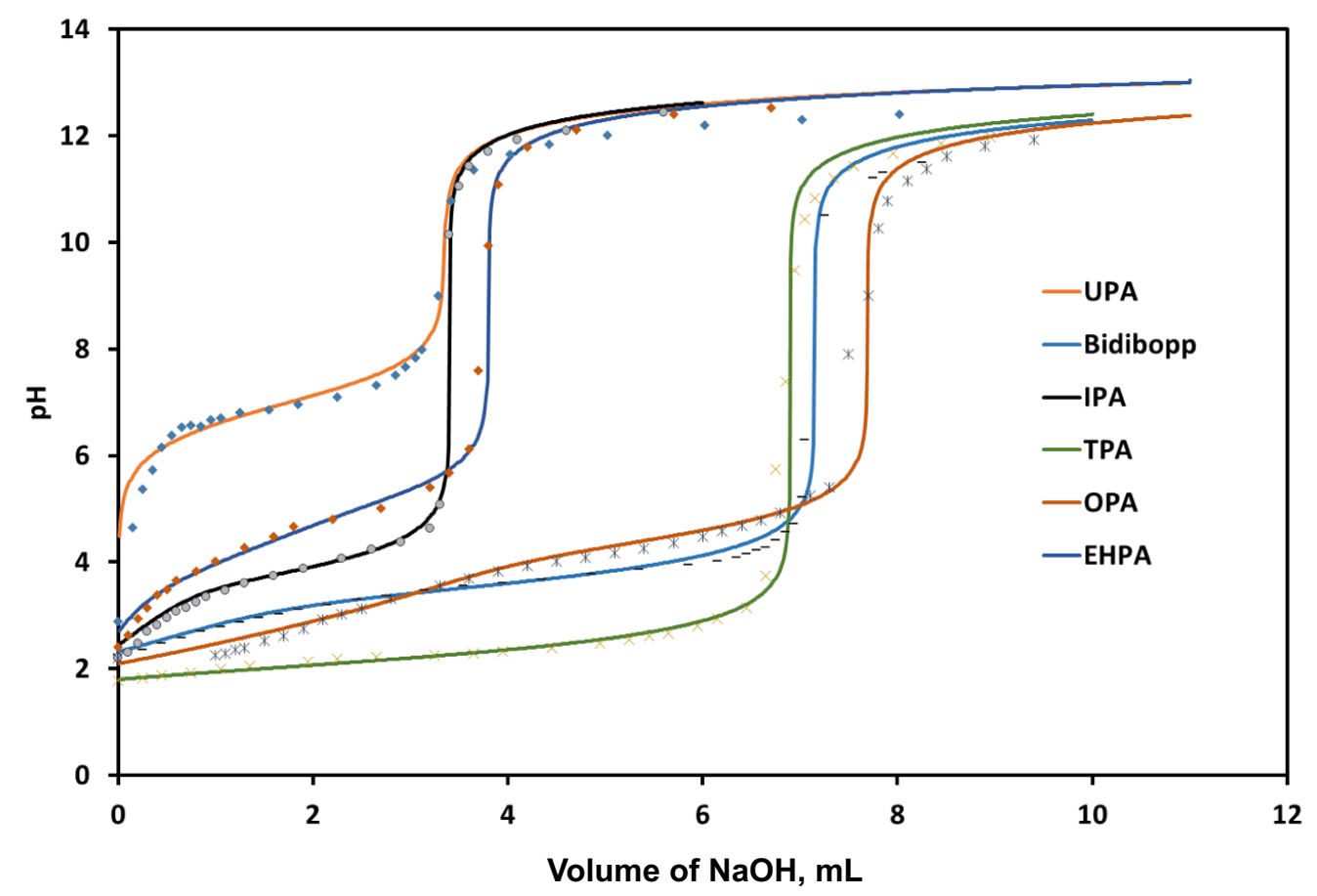

Figure 5: Experimental and calculated biphasic potentiometric titration curves at $25^{\circ} \mathrm{C}$ of the synthesized extractants diluted in kerosene. [HL] $]_{\mathrm{org}, 0}=0.1 \mathrm{~mol} \mathrm{~L}^{-1}$; $[\mathrm{NaOH}]=0.5 \mathrm{~mol} \mathrm{~L}^{-1} ;\left[\mathrm{NaClO}_{4}\right]=1 \mathrm{~mol} \mathrm{~L}^{-1} ; \mathrm{V}_{\text {org }}=20 \mathrm{~mL} ; \mathrm{V}_{\mathrm{aq}, 0}=25 \mathrm{~mL}$. Equilibrium constants used in the model are reported in Table 2. 

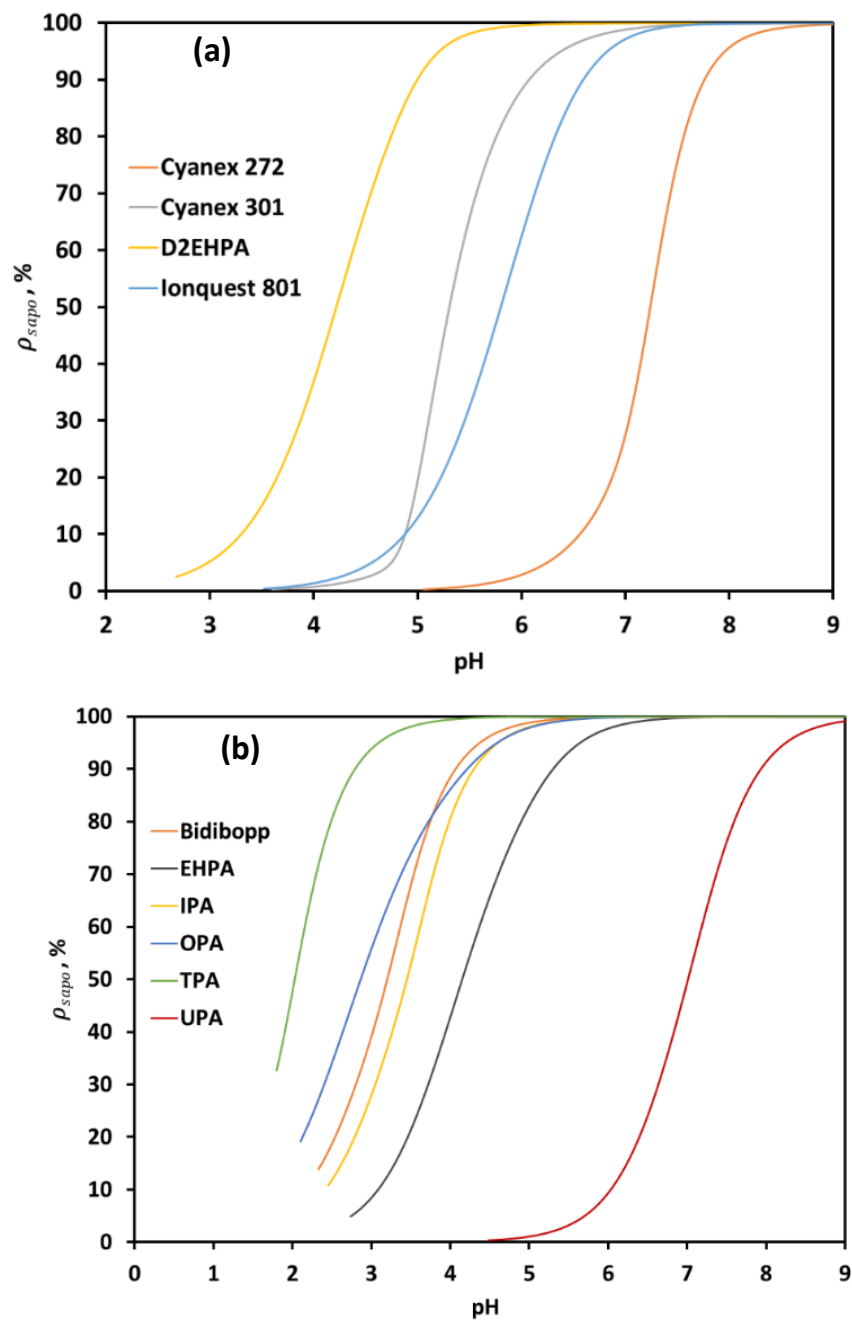

Figure 6 : Saponification percentage ( $\rho_{\text {sapo }}$ ) as a function of $\mathrm{pH}$ for the commercial and synthesized extractants diluted in kerosene at $25^{\circ} \mathrm{C}$.

$$
\begin{gathered}
3 \overline{H L} \stackrel{K_{3}}{\rightleftarrows}(\overline{H L})_{3} \\
2 \overline{H L} \stackrel{K_{2}}{\rightleftarrows}(\overline{H L})_{2}
\end{gathered}
$$

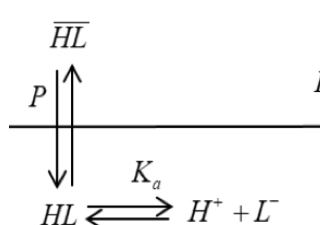

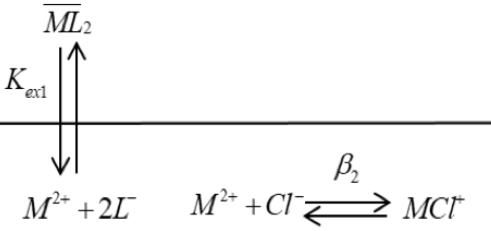

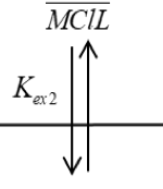

$\mathrm{MCl}^{+}+\mathrm{L}^{-}$

$$
\begin{array}{r}
n \overline{N a L} \stackrel{\beta_{n}}{\rightleftarrows}(\overline{N a L})_{n} \\
\overline{N a L}+\overline{H L} \stackrel{\beta^{\prime}}{\rightleftarrows} \overline{N a H L}_{2}
\end{array}
$$

$\overline{\mathrm{NaL}}$

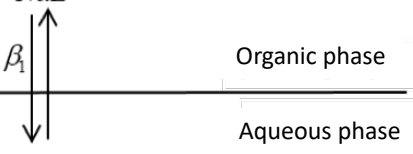

Figure 7: Equilibria implemented in the physicochemical model for the calculation of the extraction curves during the liquid-liquid extraction of $\mathrm{Co}(\mathrm{II}), \mathrm{Ni}$ (II) and $\mathrm{Mn}$ (II) from acidic chloride media (chloride concentration $=1 \mathrm{~mol} \mathrm{~L}^{-1}$ ). 

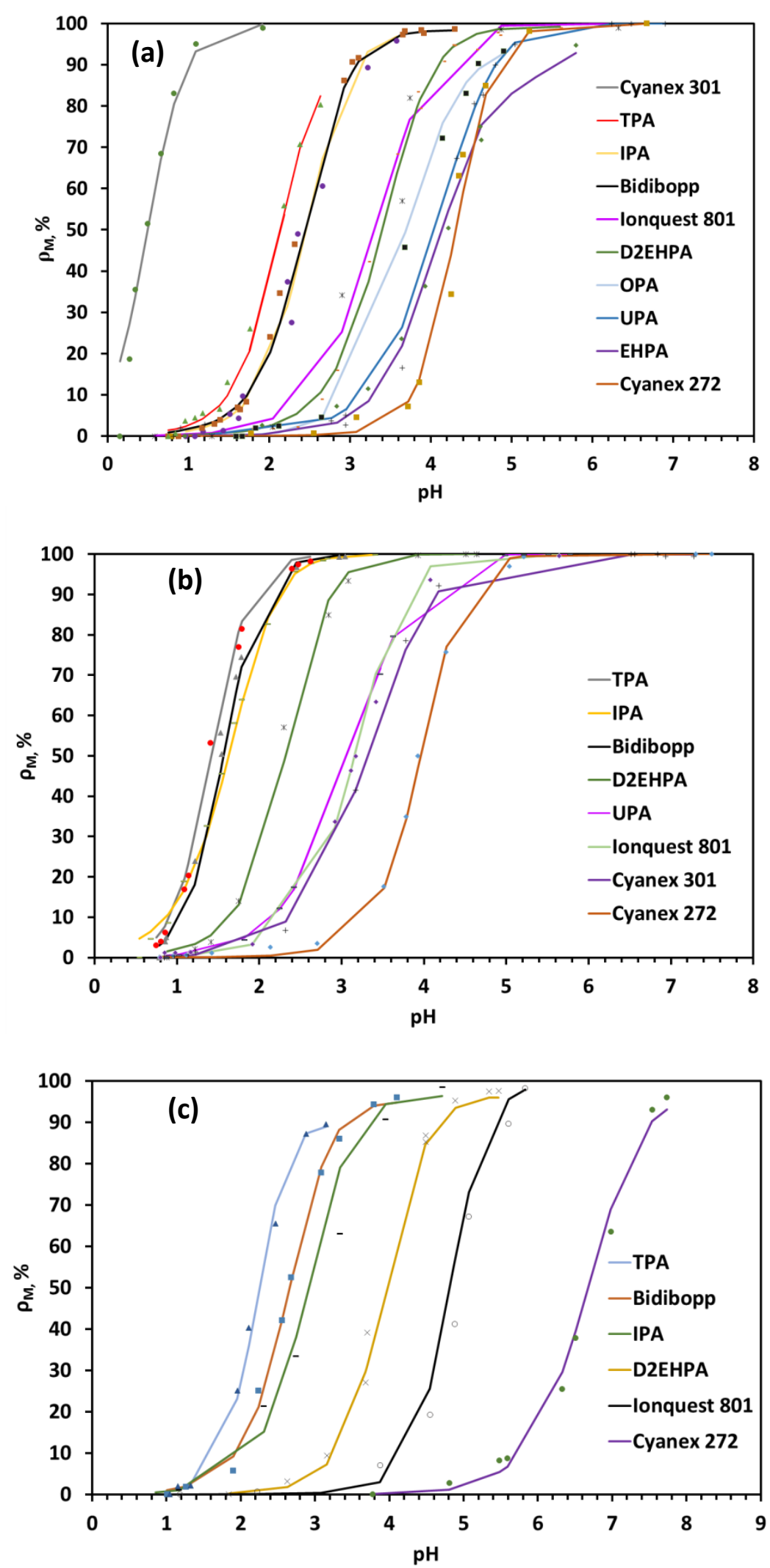

Figure 8: Experimental and calculated extraction curves at $25^{\circ} \mathrm{C}$ for (a) cobalt(II), (b) manganèse(II) and (c) nickel(II). [HL $]_{\mathrm{org}, 0}=0.25 \mathrm{~mol} \mathrm{~L}^{-1}$; $[\mathrm{HCl}]=1 \mathrm{~mol} \mathrm{~L}^{-1}$; $[\mathrm{NaOH}]=5 \mathrm{~mol} \mathrm{~L}^{-1} ;\left[\mathrm{M}^{2+}\right]_{0}=0.02 \mathrm{~mol} \mathrm{~L}^{-1} ; \mathrm{V}_{\mathrm{org}, 0}=10 \mathrm{~mL} ; \mathrm{V}_{\mathrm{aq}, 0}=10 \mathrm{~mL}$. 

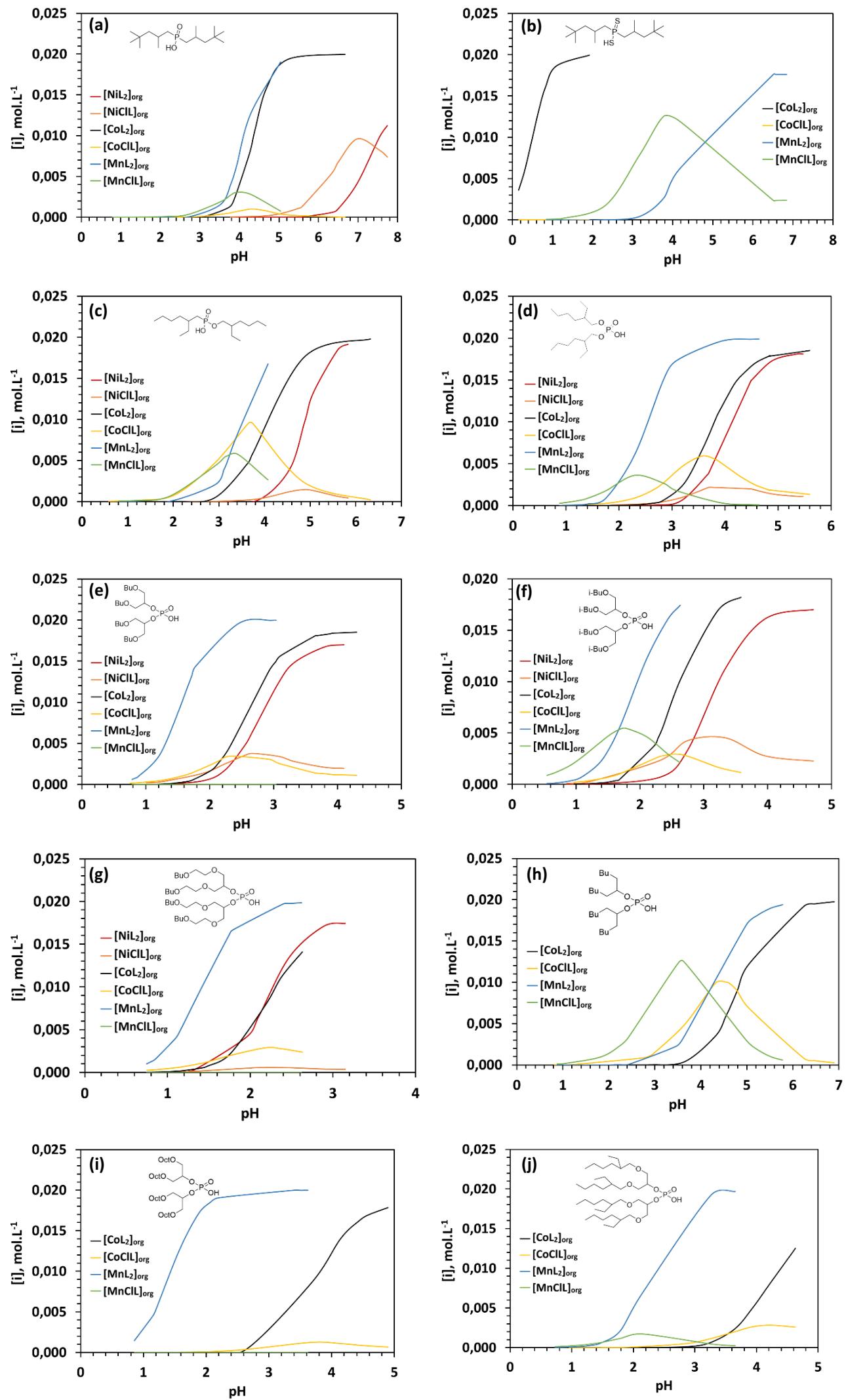

Figure 9: Speciation diagrams of $\mathrm{Co}(\mathrm{II}), \mathrm{Ni}(\mathrm{II})$ and $\mathrm{Mn}(\mathrm{II})$ in the extraction solvents. 